Soil Science and Agricultural Engineering

http:/www.journals.zu.edu.eg/journalDisplay.aspx?.Journalld=1\&queryType=Master

\title{
MECHANICAL PLANTING OF COATED MARJORAM SEEDS
}

\author{
Habiba E. Sabry ${ }^{1 *}$, M.K. Abd El-Wahab ${ }^{2}$, I. Yehia ${ }^{1}$ and A.M. El-Shal ${ }^{2}$ \\ 1. Inst. Agric. Eng., Res. Cent. Agric., Dokki, Egypt \\ 2. Agric. Eng. Dep., Fac. Agric., Zagazig Univ., Egypt
}

\section{Received: 27/11/2017 ; Accepted: 22/04/2018}

\begin{abstract}
The aim of this research is to determine the optimum factors affecting mechanical planting of coated marjoram seeds. The studied factor is four forward speed levels. The main results of this study can be summarized as follows: The maximum marjoram seeding rate of $3.50 \mathrm{~kg} / \mathrm{fad}$., was obtained at metering-device speed of $20 \mathrm{rpm}$. while, the minimum seeding rate of $2.30 \mathrm{~kg} / \mathrm{fad}$., was obtained at metering-device speed of $60 \mathrm{rpm}$. The maximum plant-emergency of $93.6 \%$ was obtained at forward speed of $1.82 \mathrm{~km} / \mathrm{hr}$. While, the minimum plant-emergence of $82.3 \%$ was obtained at forward speed of $4.79 \mathrm{~km} / \mathrm{hr}$. By increasing forward speed from 1.82 to $4.79 \mathrm{~km} / \mathrm{hr}$., the total cropyield decreased from 3200 to $2400 \mathrm{~kg} / \mathrm{fad}$. Also the minimum production-cost of $26 \mathrm{LE} / \mathrm{ton}$ was obtained using forward speed of $4.79 \mathrm{~km} / \mathrm{hr}$.
\end{abstract}

Key words: Mechanical planting, marjoram seeds.

\section{INTRODUCTION}

In Egypt, medicinal and aromatic plants represent a significant source of national income. They have an economic value for local and exterior markets. The cultivated areas in Egypt reach up to 80000 faddan (FAO Statistical Year Book, 2017)

Many constraints are facing the production, processing and marketing of medicinal plants and herbs in Egypt as follows:

- Lack of clear data on the areas of cultivation and the various crops cultivated which leads to the incapability of planning or finding alternatives.

-Lack of knowledge of modern agricultural methods.

- The rise of production costs and the small size of plots which render their cultivation expensive.

In addition, seeds of these plants are vary greatly in size, shape and color. In many cases, seed size is small or irregular, making singularization and precision placement difficult. Moreover, seeds should be protected from a range of pests that harm germination or seedlings. Seed-coating technologies can be employed for two purposes: they can facilitate mechanical sowing to achieve uniformity of plant spacing, and can act as a carrier for plant protectants. So coating materials can be applied in the target zone with minimal disruption to the soil ecology and environment (Taylor et al., 1998). Using coating materials (Fe+ $\mathrm{Zn}$ +Arasan) gave the best results of average germination of pepper seeds, where it was $62.8 \%$, with minimum and maximum germination values of 14.3 and $98.5 \%$ (Abd AlFattah, 2016). Designed a coating machine for crop seeds and found that the maximum wheatgrain germination of $98.1 \%$ was obtained with coating temperature of $40 \mathrm{C}^{\circ}$ and coating time of $30 \mathrm{~min}$. Meanwhile, the minimum wheat-grain germination of $38.3 \%$ was obtained with coating temperature of $70 \mathrm{C}^{\circ}$ and coating time of $60 \mathrm{~min}$ (Yehia, 2008). Coating time of $30 \mathrm{~min}$ and temperature of $50-60^{\circ} \mathrm{C}$ are used commercially

Corresponding author: Tel. : +201278451748

E-mail address: habibaamro941@yahoo.com 
for some small-seed species, e.g. flowers and celery. Success depends on finding conditions lethal to the pathogen with minimal damage to seed quality (Chandra and Ingle, 2010). The fennel, caraway, coriander, nigella and guar seeds germination decreased by 22.5 - 22.9, 22.8 - 24.4, $18.9-29.8,20.1-27.5$ and $18.1-$ $23.7 \%$ by increasing coating temperature from 40 to $70^{\circ} \mathrm{C}$. Meanwhile, the fennel, caraway, coriander, nigella and guar seeds germination decreased by $16.7-35.4,17.1-36,16.6-32.3$, $15.2-32.2$ and $14.3-29.8 \%$ by increasing coating time from 30 to $60 \mathrm{~min}$ (Yehia et al., 2010). Karayel (2011) found that by increasing forward speed from 1 to $2 \mathrm{~m} / \mathrm{sec}$, the mean soybean seeds spacing increased from 99 to 104 $\mathrm{mm}$ and precision spacing increased from 19.7 to $29.8 \%$, the miss index of soybean seeds increased from 8.2 to $25.9 \%$, and the mean depth decreased from 51 to $43 \mathrm{~mm}$ and the coefficient of variation of depth increase from 14.7 to $18.9 \%$. Sahoo and Srivastava (2008) evaluated four different types of metering systems on the basis of their performance parameters i.e. average spacing, quality of feed index, multiple index, miss index, degree of variation and seed damage for metering soaked okra seed at three levels of cell size and four levels of cell speed. They observed that average spacing was close to the theoretical spacing for cell size equal to maximum seed dimension. The quality of feed index 13 was influenced highly by metering systems, cell size and cell speed. They reported that metering systems influenced mostly the seed damage followed by cell size. They concluded that the inclined plate metering system was best suited for metering soaked okra seed.

Because of the high costs of the traditional methods of medicinal and aromatic-crops planting, cultivation and harvesting consuming more time and labor, its large scale production is not economical and was therefore very limited.

In Egypt, different planting machines are used. From this point of view, many small workshops produce planting machines without any scientific guidance. For this reason, such care had to be taken to operate medicinal and aromatic-crop seed-coating and manufacturing planting machines with an accurate scientific guidance taking into consideration machine efficiency, seed uniformity, energy and cost requirements.

The objectives of this research are to:

1. Develop and evaluate a planter for planting marjoram coating seeds.

2. Evaluate the developed planter from the economic point of view.

\section{MATERIALS AND METHODS}

\section{Materials}

\section{Coating operation}

Coating operation was carried out according to Abd Al-Fattah et al. (2015) and Abd AlFattah (2016). Views of this machine is shown in Fig. 1.

The physical properties of marjoram seeds before coating were $0.27,0.24$ and $0.2 \mathrm{~mm}$ length, width and thickness, while they were 4.4 , 3.6 and $2.9 \mathrm{~mm}$ after coating respectively. The agronomic requirements of this crop included seeds rate, row spacing, and distance between seeds are shown in Table 1.

\section{Developed planter}

The developed planter, as shown in Fig. 2, consists of the main frame with the tool bar and three hitching points and two planting units. The overall dimensions of the developed planter are $1730 \mathrm{~mm}$ in length, $1075 \mathrm{~mm}$ in width and 1035 $\mathrm{mm}$ in height and its mass is about $185 \mathrm{~kg}$.

\section{Metering device}

A vertical axis metering wheel $(200 \mathrm{~mm}$ diameter) with cells was developed regarding the seed size after coating. Fourteen cylindricalcells on wheel were located at the periphery. Coated seeds are picked up by each cell from the hopper and dropped into the seed tube. The designed and tested cell has a diameter of $6 \mathrm{~mm}$ and depth of $6 \mathrm{~mm}$. The vertical axes roller metering-device was tested for its effect on visible and invisible seed damage at different metering-device speeds.

\section{Tractor}

Kubota of $22.07 \mathrm{~kW}$ (30 hp) was used for operating the developed planter. 
Zagazig J. Agric. Res., Vol. 45 No. (4) 2018

Table 1. Seed rate, row spacing and distance between seeds of marjoram crop

\begin{tabular}{lccccc}
\hline Crop & Variety & $\begin{array}{c}\text { Seeding rate, kg coated } \\
\text { (seeds/fad.) }\end{array}$ & $\begin{array}{c}\text { No. of } \\
\text { plants/fad. }\end{array}$ & $\begin{array}{c}\text { Row spacing } \\
(\mathbf{c m})\end{array}$ & $\begin{array}{c}\text { Seed spacing } \\
(\mathbf{c m})\end{array}$ \\
\hline Marjoram & Baladi & 3.5 & 28000 & 50 & 30 \\
\hline
\end{tabular}

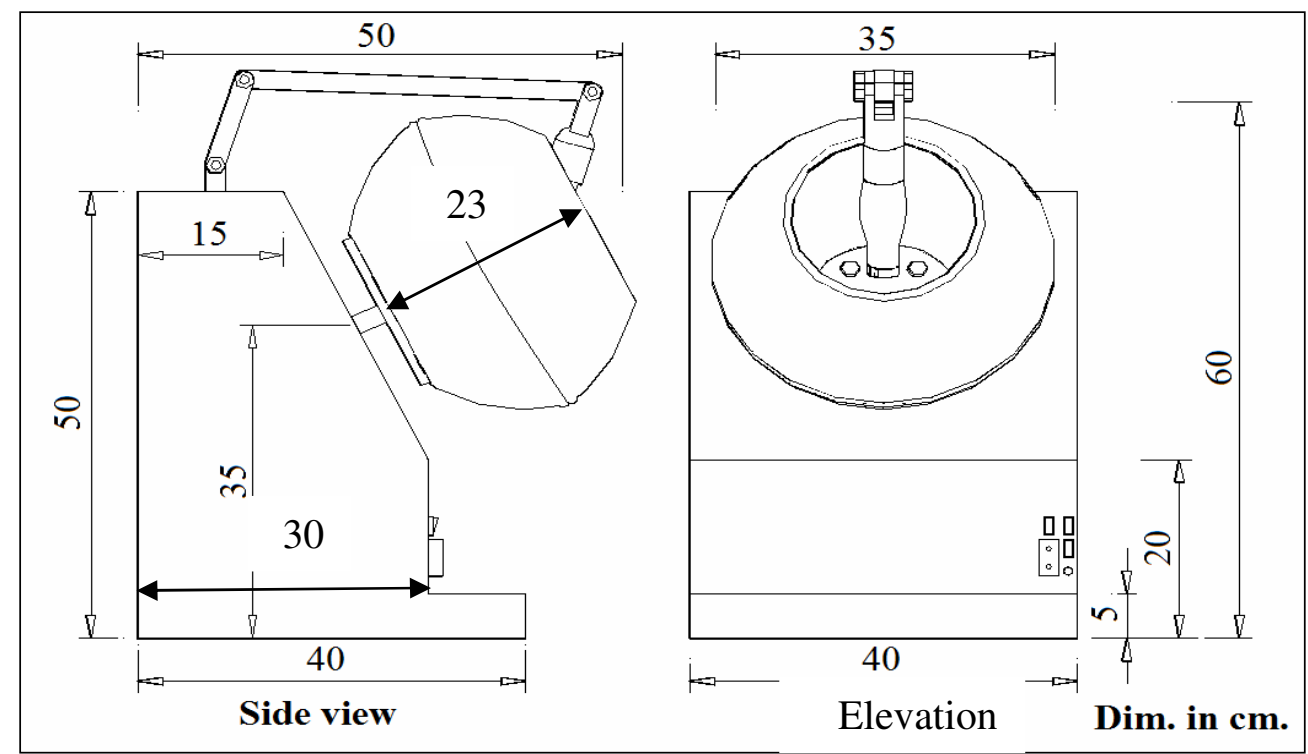

Fig. 1. Views of the seed-coating machine (Abd-Al Fattah et al., 2015; Abd-Al Fattah, 2016)

\section{Laboratory planting tests}

Laboratory experiments were conducted to optimize the following parameters:

\section{Metering-device speed}

Five metering-device speeds of 20,30, 40, 50 and $60 \mathrm{rpm}(0.21,0.31,0.42,0.52$ and 0.63 $\mathrm{m} / \mathrm{sec})$ corresponded to ground wheel $(470 \mathrm{~mm}$ diameter) speeds of 55,82,109, 137 and 163 $\operatorname{rpm}(1.34,2.01,2.69,3.36$ and $4.03 \mathrm{~m} / \mathrm{sec})$.

To optimize the laboratory parameters, the following indicators were taken into consideration.

\section{Seeding rate}

Seeding rate was measured by rotating the press wheel. The fed seeds were collected in plastic bag during a certain number of feeding shaft revolutions and consequently seeding rate was determined.

\section{Seeds damage}

For the previously mentioned factors, the damaged seeds including any significant bruising, skin removal or crushing were sorted manually and weighed.

The visible damage of seeds after passing through the metering device was calculated by the following equation:

Visible damage $(\%)=\frac{\text { No. of damaged seeds }}{\text { Total No. of seeds }} \times 100$

\section{Field experiments}

Field experiments were carried out under four forward-speeds of 1.82, 2.97, 3.84 and 4.79 $\mathrm{km} / \mathrm{hr}$., (metering device speeds of $8,12,16$ and $20 \mathrm{rpm}$ and ground wheel speeds of $21,34,44$ and $55 \mathrm{rpm}$ ). To evaluate effects of the field parameters, the following indicators were taken into consideration.

\section{Plant scattering}

The variations of plant distribution were determined by estimating the coefficient of variation $(\mathrm{CV})$ of seeds spacing according to the following formula (Yehia, 1993): 


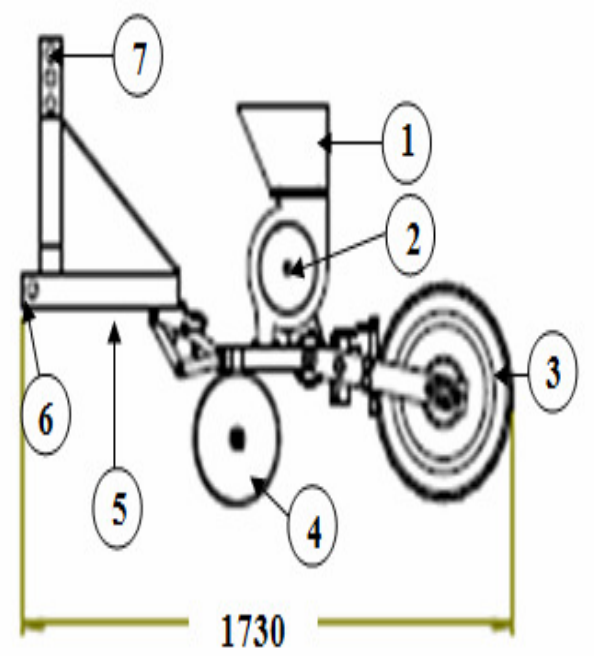

Side view

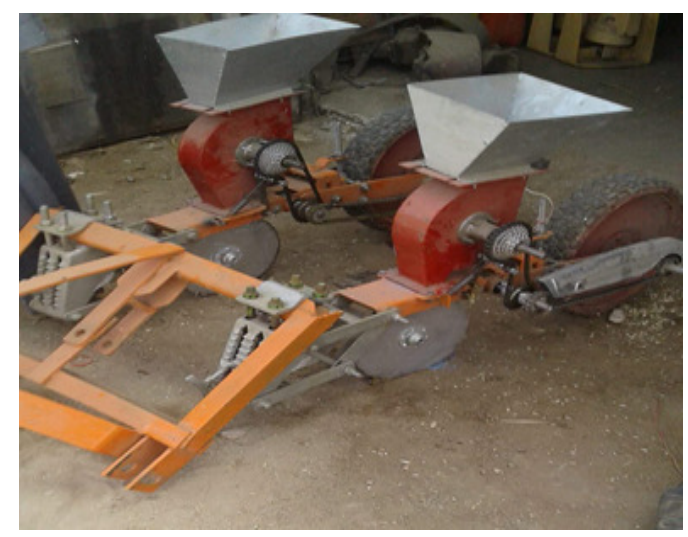

Photo of the developed planter

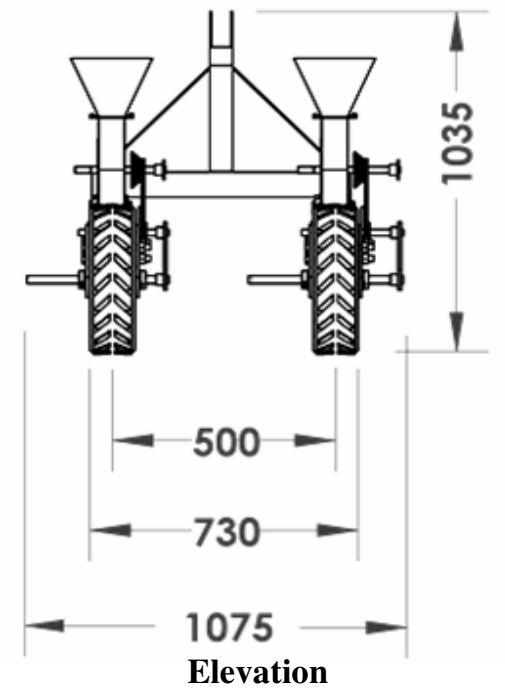

\begin{tabular}{ccc}
\hline No. & Part name & No. of pars \\
\hline 1 & Seed box & 2 \\
2 & Metering device & 2 \\
3 & Press wheel & 2 \\
4 & Double disc furrow opener & 2 \\
5 & Tool bar & 1 \\
6 & Two lower hitching points & 2 \\
7 & Upper hitching point & 3 \\
\hline
\end{tabular}

Fig. 2. Elevation, side view and photo of the developed planter

$$
\begin{aligned}
\mathrm{CV}(\%) & =\frac{\mathrm{SD} \text { of seeds spacing }}{\text { Recommended seeds spacing }} \times 100 \\
\mathrm{SD} & =\sqrt{\frac{\sum \text { (Plant spacing - }}{\text { Recommended seeds spacing })^{2} / \mathrm{n}}}
\end{aligned}
$$

Where:

$\mathrm{SD}$ is the standard deviation.

$\mathrm{n}$ is number of seed spacing

\section{Missing hills percentage}

Missing-hills percentage or missing index indicates the incapability of seed metering unit to drop even a single seed within the desired range of seed spacing. Missing percentage or index is the indicator of how often the seed skips the desired spacing. It is the percentage of spacing greater than 1.5 times the theoretical spacing. The missing-hill percentage or index was calculated according to the following formula (Grewal, 2014):

Missing hills =

$\frac{\text { Number of missing plants per meter }}{\text { Total plants per meter }} \times 100$

\section{Double plants percent}

Multiple index explores that two or more seeds are picked and dropped by the seed metering device in a single cell in the metering device. The multiple index is an indicator of more than one seed dropped within a desired spacing. It is the percentage of spacing that are less than or equal to half of the theoretical 
spacing. The objective of measuring this indicate is to minimize the multiples to save costly seeds and to subsequently reduce the labor required for thinning the extra plant population (Grewal, 2014).

$$
\text { Double plants }=\frac{\mathrm{n} 1}{\mathrm{~N}} \times 100
$$

Where:

$\mathrm{n} 1=$ Number of spacing that are less than or equal to half of the theoretical spacing in the given observations

$\mathrm{N}=$ Total number of observations

\section{Emergence percentage}

The number of plants per meter of row was counted as affecting by the four tested speeds to determine emergence ratio according to the following formula:

Emergence percentage $=\frac{\text { Germinated seeds }}{\text { Total seeds }} \times 100$

\section{Crop yield}

Two rows of the tested with $10 \mathrm{~m}$ length for each forward speed were harvested by manual tool and weighed by analog balance. Then the yield was calculated according to the following formula:

$$
\text { Yield }(\mathrm{kg} / \mathrm{fad} .)=\frac{\text { Mass }(\mathrm{kg})}{\text { Area }(\text { fad. })}
$$

\section{Ground wheel slip ratio}

The slippage is an important factor that affects the planter performance. The percentages of slip were estimated versus the four forwardspeeds using the following equation.

Slippage $(\%)=$

Distance without load - Distance with load

$$
\text { Distance without load }
$$

\section{Specific energy}

Specific energy can be calculated by using the following equation:

$$
\begin{aligned}
& \text { Specific energy }(\mathrm{kW} . \mathrm{hr} . / \mathrm{fad} .)= \\
& \frac{\text { Required power }(\mathrm{kW})}{\text { Actual field capacity }(\mathrm{fad} . / \mathrm{hr} .)}
\end{aligned}
$$

\section{Cost analysis}

The operation cost of the developed planter was calculated according to equation of (Awady, 1978).

$$
\mathrm{C}=\frac{\mathrm{P}}{\mathrm{h}}\left(\frac{1}{\mathrm{a}}+\frac{\mathrm{i}}{2}+\mathrm{t}+\mathrm{r}\right)+(0.9 \times \mathrm{w} \times \mathrm{s} \times \mathrm{f})+\frac{\mathrm{m}}{144}, \mathrm{LE} / \mathrm{hr} .
$$

Where:

$\mathrm{C}=$ hourly cost, LE/hr.; $\mathrm{p}=$ price of machine LE; $\mathrm{h}=$ yearly working hours, hr./year; $\mathrm{a}=$ life expectancy of the machine, year; $\mathrm{i}=$ interest rate/year, \%; $\mathrm{t}=$ taxes and overheads, \%; $\mathrm{r}=$ repairs and maintenance, $\% ; \mathrm{w}=$ power of the machine, hp.; $\mathrm{s}=$ Specific fuel consumption, L/ hp.hr.; $\mathrm{f}=$ fuel price, LE/L.; $0.9=$ factor accounting for ratio of rated power and lubrications,

$$
\begin{aligned}
& \text { Cost per unit of production }(\mathrm{LE} / \mathrm{Mg})= \\
& \frac{\text { Operational cost }(\mathrm{LE} / \mathrm{fad} .)}{\text { Crop yield }(\mathrm{Mg} / \mathrm{fad} .)}
\end{aligned}
$$

\section{RESULTS AND DISCUSSION}

The results of the present study could divided into two main divisions as follow (results of laboratory planting experiments and results planting of field experiments).

\section{Results of Laboratorial Planting Experiments}

Laboratory experiments were carried out to study the effect of metering-device speed on the performance of the manufactured metering-device for marjoram coated-seeds. Laboratory experiments help to adjust the machine under the optimum conditions during the filed experiments.

\section{Effect of metering-device speed on coated- seeding rate}

Fig. 3 shows the effect of metering-device speed on coated-seeding rate for marjoram. Results showed that seeding rate decreased by increasing metering-device speed.

The maximum seeding rate $(3.50 \mathrm{~kg} / \mathrm{fad}$.) was obtained at metering-device speed of 20 rpm, while, the minimum seeding rate $(2.30 \mathrm{~kg} /$ fad.) was obtained at metering-device speed of $60 \mathrm{rpm}$. 


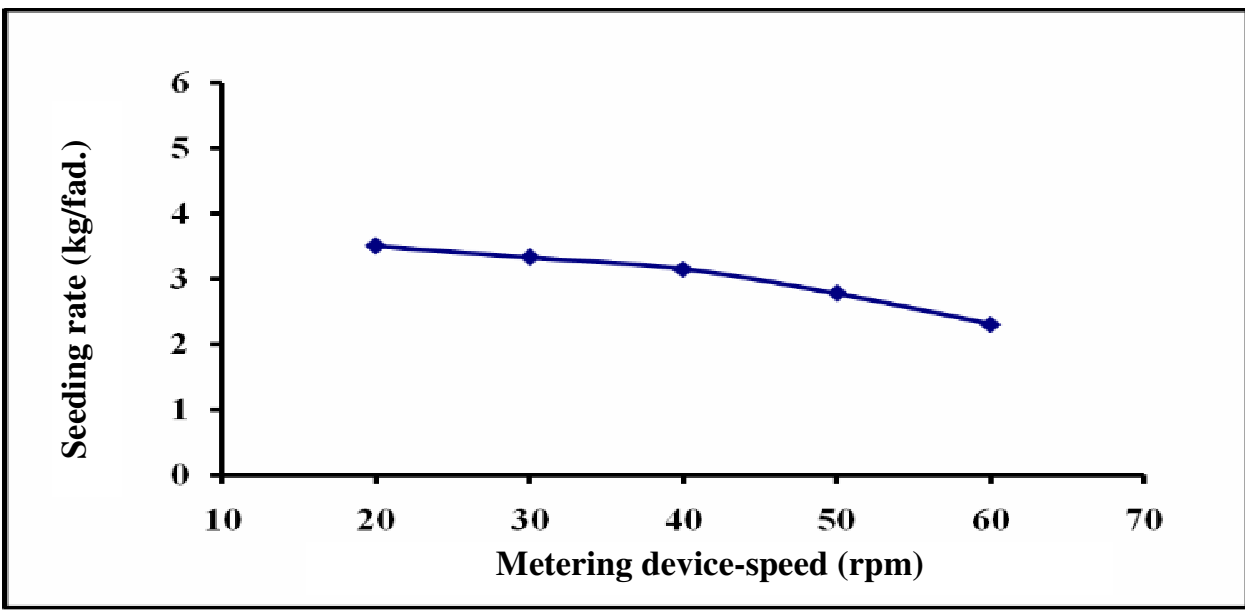

Fig. 3. Effect of metering-device speed on coated seeding rates of marjoram

Results showed that by increasing meteringdevice speed from 20 to $60 \mathrm{rpm}$ the seeding rate was decreased by $34.3 \%$. The decreasing of coated seeding rate by increasing metering device speed could be due to the time which was not enough to fill all cells of metering-device.

Effect of metering-device speed on coatedseed damage ratio

Fig. 4 shows the effect of metering-device speed on coated-seed damage for marjoram. Results showed that seed damage increased by increasing metering-device speed. The maximum coated-seed damage $(2.30 \%)$ was obtained at metering-device speed of $60 \mathrm{rpm}$, while the minimum coated-seed damage $(0.26 \%)$ was obtained at metering-device speed of $20 \mathrm{rpm}$.

Results showed that increasing metering-device speed from 20 to $60 \mathrm{rpm}$ the marjoram coatedseeds damage increased from 0.26 to $2.3 \%$

The increase in coated-seed damage by increasing metering device speed from 20 to 60 $\mathrm{rpm}$ is due to increasing momentum of seeds (momentum $=$ mass $\times$ velocity) and increasing impact force accordingly.

\section{Effect of metering-device speed on coated-} seed germination ratio

Fig. 5 shows the effect of metering-device speed on marjoram coated-seeds germination. Results showed that coated-seed germination decreased by increasing metering-device speed.
The maximum marjoram coated-seeds germination of $90.3 \%$ was obtained at meteringdevice speed of $20 \mathrm{rpm}$. Meanwhile, the minimum marjoram coated-seeds germination of $82.6 \%$ was obtained at metering-device speed of $60 \mathrm{rpm}$.

Results showed that by increasing meteringdevice speed from 20 to $60 \mathrm{rpm}$ the marjoram coated-seeds germination decreased by $8.5 \%$.

\section{Results of Field Planting Experiments}

\section{Effect of forward speed on planter performance}

\section{Plant emergence ratio}

Fig. 6 shows the effect of forward speed on marjoram plant-emergence. Results showed that plant emergence decreased by increasing forward speed. The maximum marjoram plantemergence of $93.6 \%$ was obtained at forward speed of $1.82 \mathrm{~km} / \mathrm{hr}$. Meanwhile, the minimum marjoram plant-emergence of $82.3 \%$ was obtained at forward speed of $4.79 \mathrm{~km} / \mathrm{hr}$.

Results showed that by increasing forward speed from 1.82 to $4.79 \mathrm{~km} / \mathrm{hr}$., the marjoram plant emergence decreased from 93.6 to $82.3 \%$.

The decrease of plant emergence by increasing forward speed is due to the increase of metering device speed and the momentum of seeds which causes seed damage accordingly. Also, planting depth could not be thoroughly adjusted at high speed that tends to decrease plant emergence. 


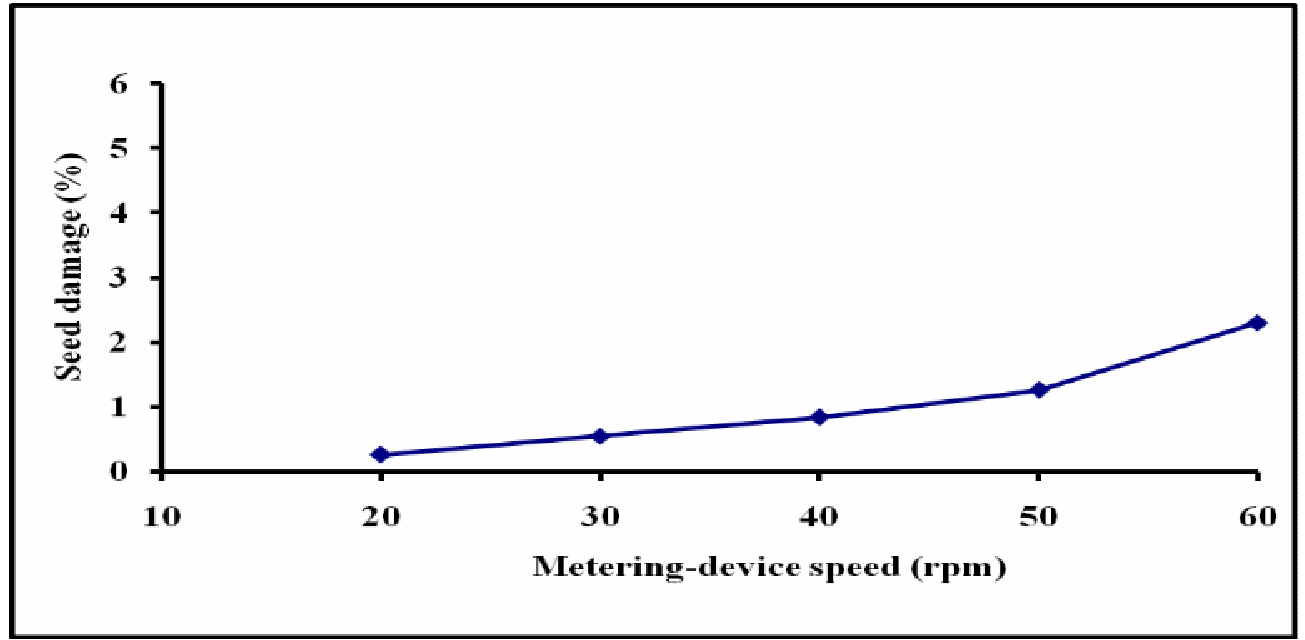

Fig. 4. Effect of metering-device speed on coated-seed damage

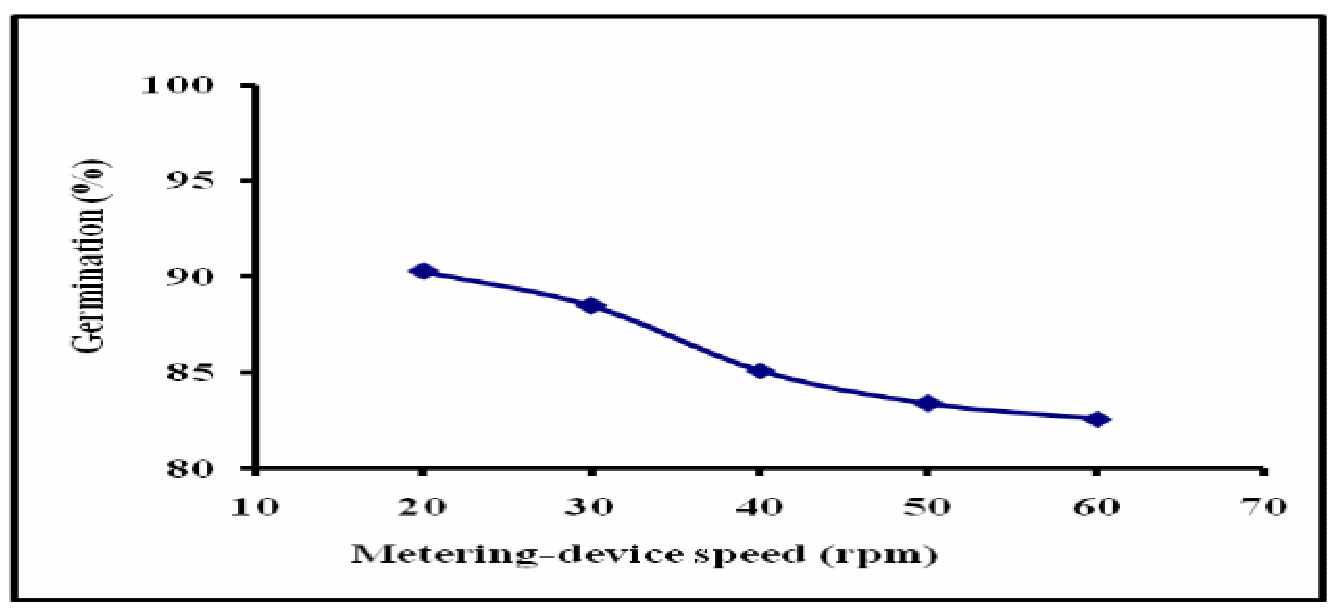

Fig. 5. Effect of metering-device speed on marjoram coated-seed germination

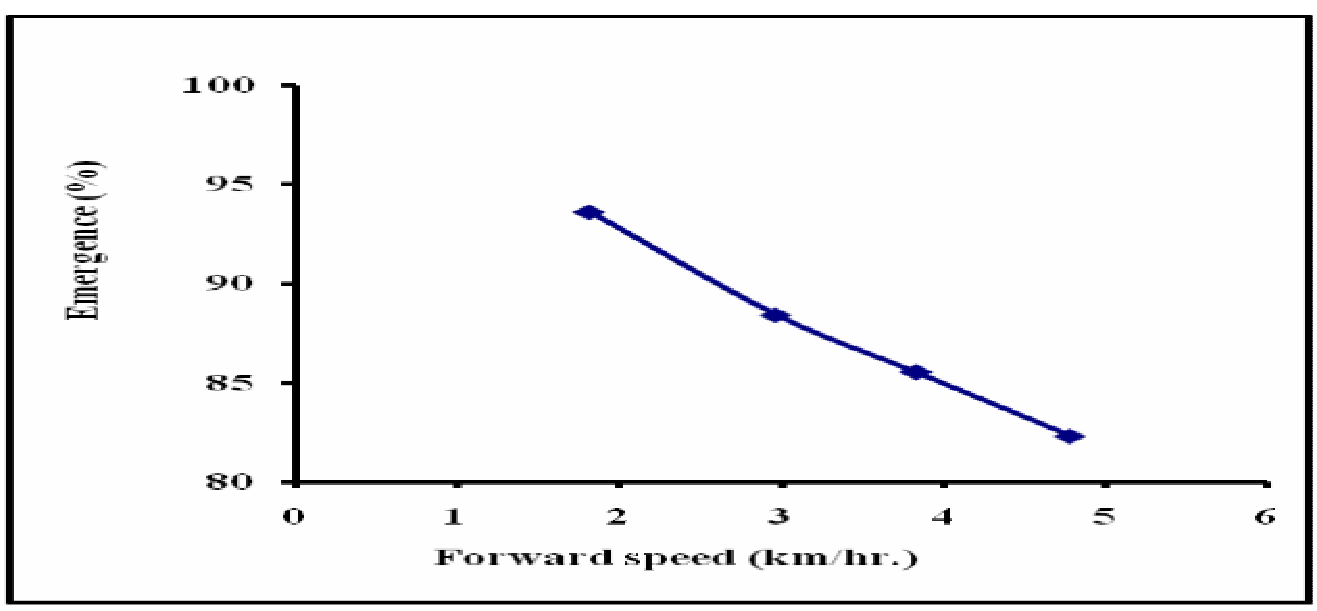

Fig. 6. Effect of forward speed on marjoram plant-emergence 
Longitudinal plants-distribution and plant scattering

The plants distribution was analyzed in order to determine the frequency, average and coefficient of variation $(\mathrm{CV})$ of marjoram plantspacing. A low CV represents a row with more uniform seed spacing.

Fig. 7 shows the effect of forward speed on average and $\mathrm{CV}$ of marjoram plant-spacing.

The optimum conditions clarify that the forward speed of $1.82 \mathrm{~km} / \mathrm{hr}$., had the best longitudinal seed distribution (average marjoram plant-spacing of $24.6 \mathrm{~cm}$, and $\mathrm{CV}$ of $1.9 \%$.

The increase of plant scattering by increasing forward speed may be due to increasing groundwheel slip in addition to the increase of machine vibration.

\section{Missing hills and double plants index}

Fig. 8 shows the effect of forward speed on missing hills and double marjoram-plants. Missing hills increased with increasing forward speed. Double plants decreased with increasing forward speed.

Results showed that by increasing forward speed from 1.82 to $4.79 \mathrm{~km} / \mathrm{hr}$., the missing-hills percent increased from 1.25 to $3.75 \%$. Also, results showed that by increasing forward speed from 1.82 to $4.79 \mathrm{~km} / \mathrm{hr}$., the double-marjoramplant percent or multiple index decreased from 32.5 to $2.5 \%$. The increasing of missing hills by increasing forward speed is due to increasing ground wheel slip.

\section{Total crop-yield}

Fig. 9 shows the effect of forward speed on total marjoram crop-yield. The total crop-yield decreased with increasing forward speed.

Results showed that by increasing forward speed from 1.82 to $4.79 \mathrm{~km} / \mathrm{hr}$., the total marjoram crop-yield decreased from 3200 to $2400 \mathrm{~kg} / \mathrm{fad}$.

The decrease in total crop-yield by increasing forward speed is due to the low plant emergence resulting from ground-wheel slip at high speed and also due to increasing seed damage occurred by increasing metering-device speed.

\section{Effect of forward speed on actual field capacity and field efficiency}

Fig. 10 shows the effect of forward speed on actual field capacity and field efficiency. The actual field capacity increased and field efficiency decreased with increasing forward speed.

The maximum actual field capacity of 0.88 fad./hr., was obtained at forward speed of 4.79 $\mathrm{km} / \mathrm{hr}$. Meanwhile, the minimum actual fieldcapacity of $0.38 \mathrm{fad} . / \mathrm{hr}$. was obtained at forward speed of $1.82 \mathrm{~km} / \mathrm{hr}$.

The maximum field efficiency of $88.37 \%$ was obtained at forward speed of $1.82 \mathrm{~km} / \mathrm{hr}$. Meanwhile, the minimum field efficiency of $77.19 \%$ was obtained at forward speed of 4.79 $\mathrm{km} / \mathrm{hr}$.

Decreasing field efficiency by increasing forward speed is due to the less theoretical time consumed in comparison with the other items of time losses.

\section{Effect of forward speed on ground-wheel slip ratio}

Fig. 11 shows the effect of forward speed on ground-wheel slip ratio. The ground-wheel slip increased with increasing forward speed.

The maximum slip of $5.98 \%$ was obtained at forward speed of $4.79 \mathrm{~km} / \mathrm{hr}$. Meanwhile the minimum slip of $3.16 \%$ was obtained at forward speed of $1.82 \mathrm{~km} / \mathrm{hr}$.

\section{Fuel consumption, required power and specific energy}

Fig. 12 shows the effect of forward speed on fuel consumption, required power and specific energy. Fuel consumption, required power and specific energy for operating the developed machine increased with increasing forward speed. By increasing forward speed from 1.82 to $4.79 \mathrm{~km} / \mathrm{hr}$., fuel consumption increased from 0.59 to $1.55 \mathrm{~L} / \mathrm{hr}$., required power increased from 1.90 to $5.00 \mathrm{~kW}$ and specific energy increased from 5.00 to $5.69 \mathrm{~kW} . \mathrm{hr} . / \mathrm{fad}$.

The maximum fuel consumption, required power and specific energy of $1.55 \mathrm{~L} / \mathrm{hr}$., $5.00 \mathrm{kw}$ and $5.69 \mathrm{~kW} . \mathrm{hr} . / \mathrm{fad}$., were obtained at forward speed of $4.79 \mathrm{~km} / \mathrm{hr}$. Meanwhile the minimum fuel consumption, required power and specific energy of $0.59 \mathrm{~L} / \mathrm{hr}$., $1.90 \mathrm{~kW}$ and $5.00 \mathrm{kw} . \mathrm{hr}$. /fad., were obtained at forward speed of $1.82 \mathrm{~km} / \mathrm{hr}$.

\section{Cost of using the developed planter}

Table 2 shows the effect of forward speed on operation and production cost for marjoram mechanical-planting. 

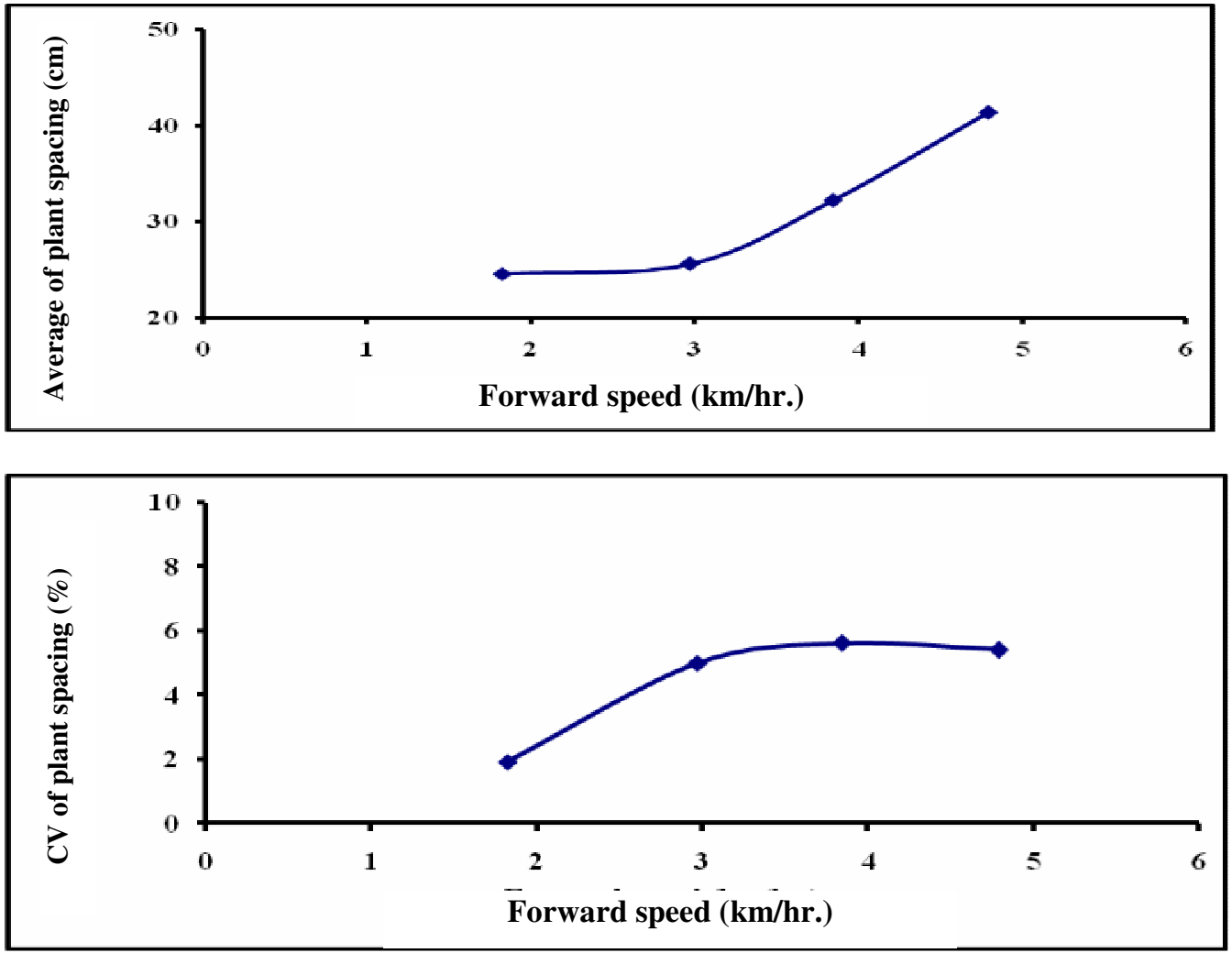

Fig.7. Effect of forward speed on average and coefficient of variation of marjoram plant-spacing
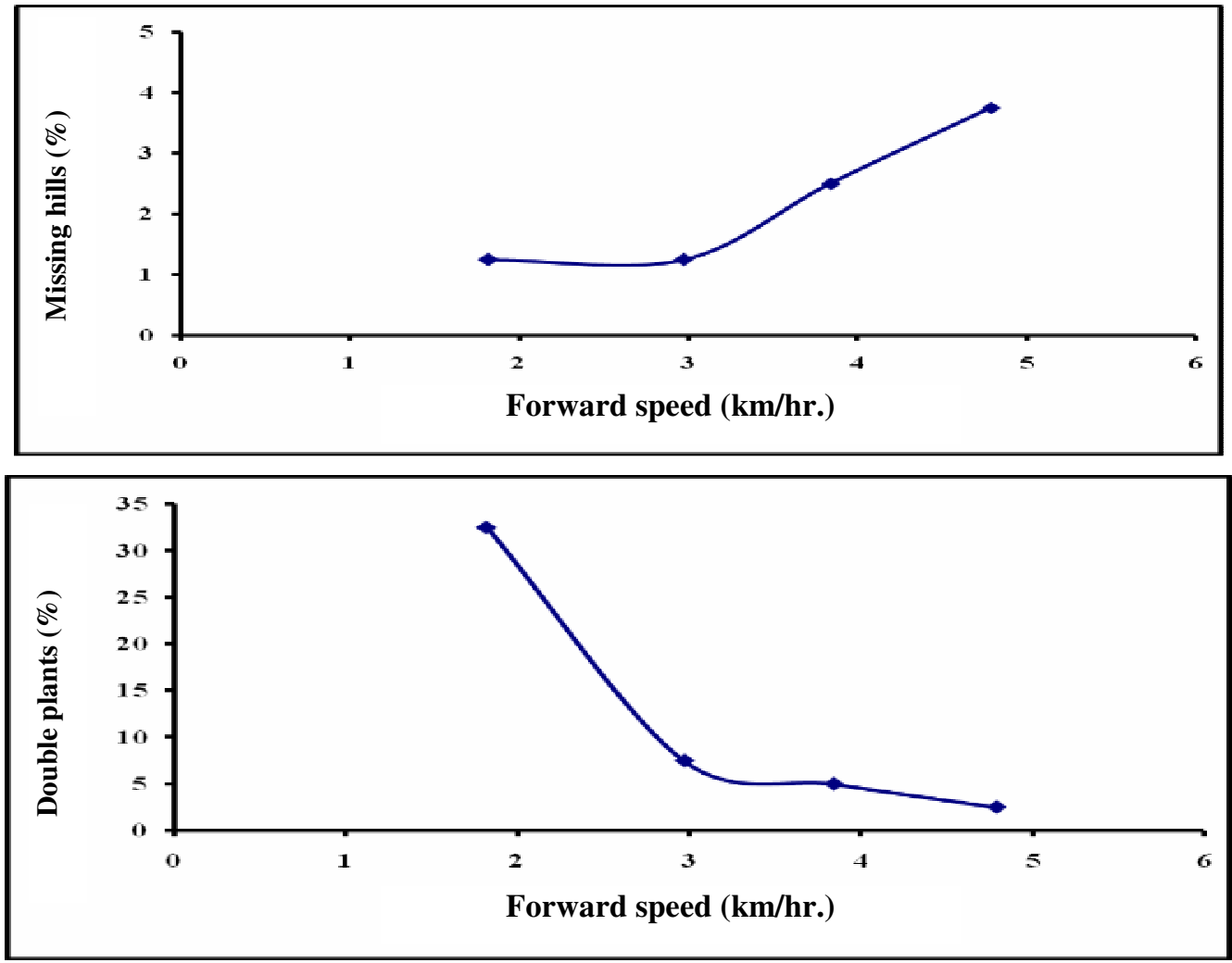

Fig. 8. Effect of forward speed on missing hills and double marjoram-plants 


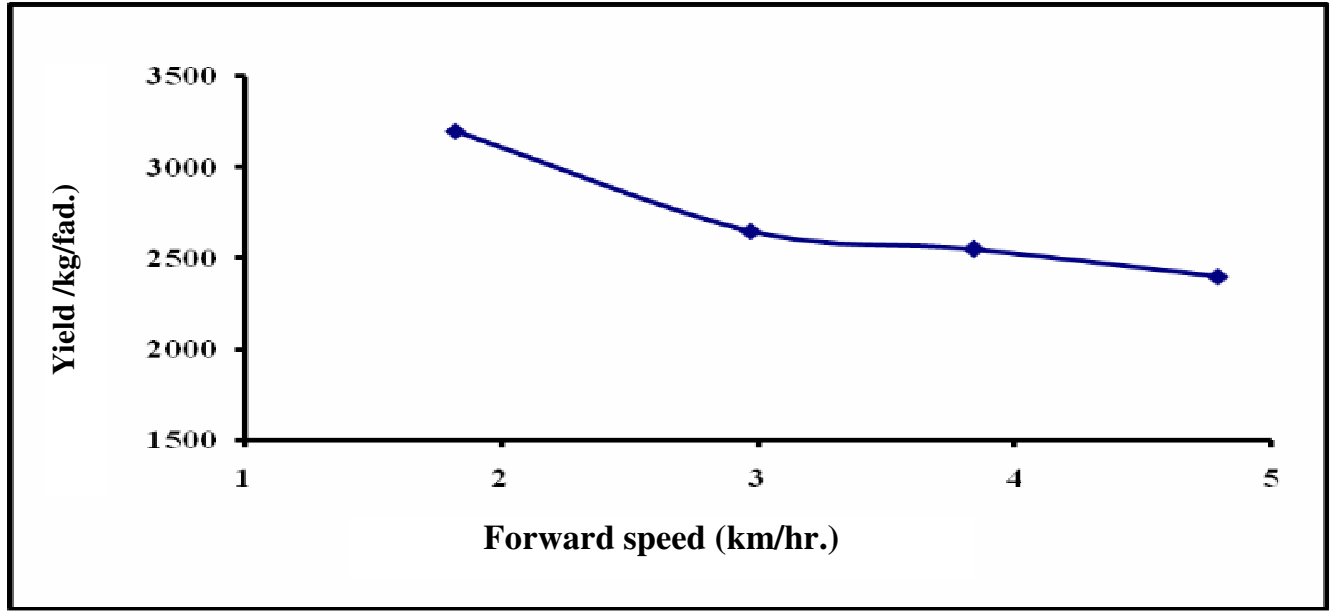

Fig. 9. Effect of forward speed on marjoram crop-yield

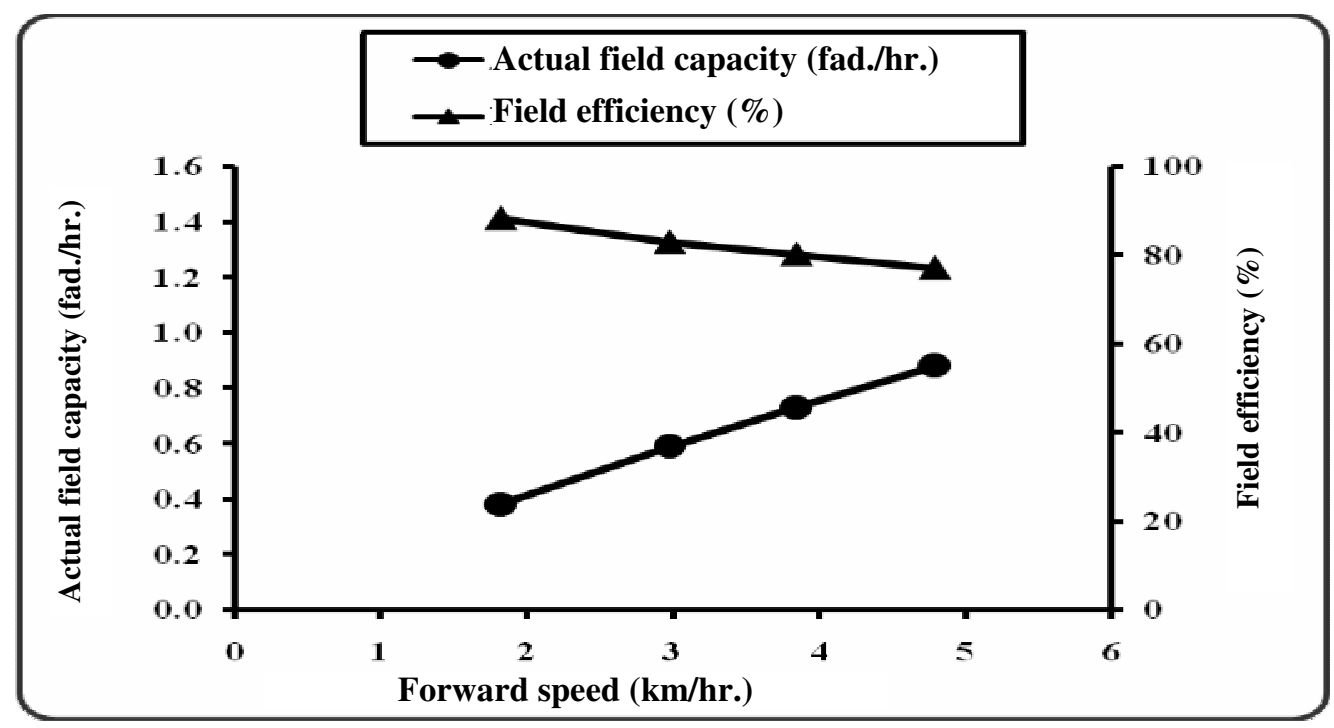

Fig. 10. Effect of forward speed on actual field capacity and field efficiency

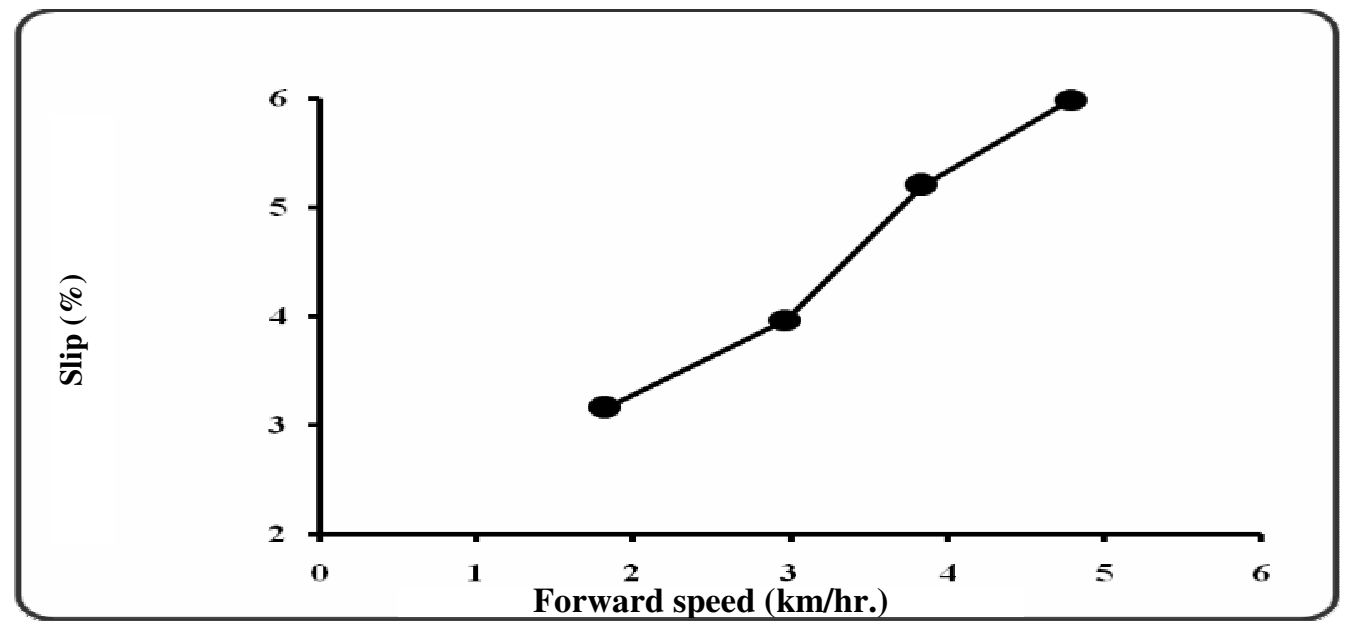

Fig. 11. Effect of forward speed on ground-wheel slip ratio 


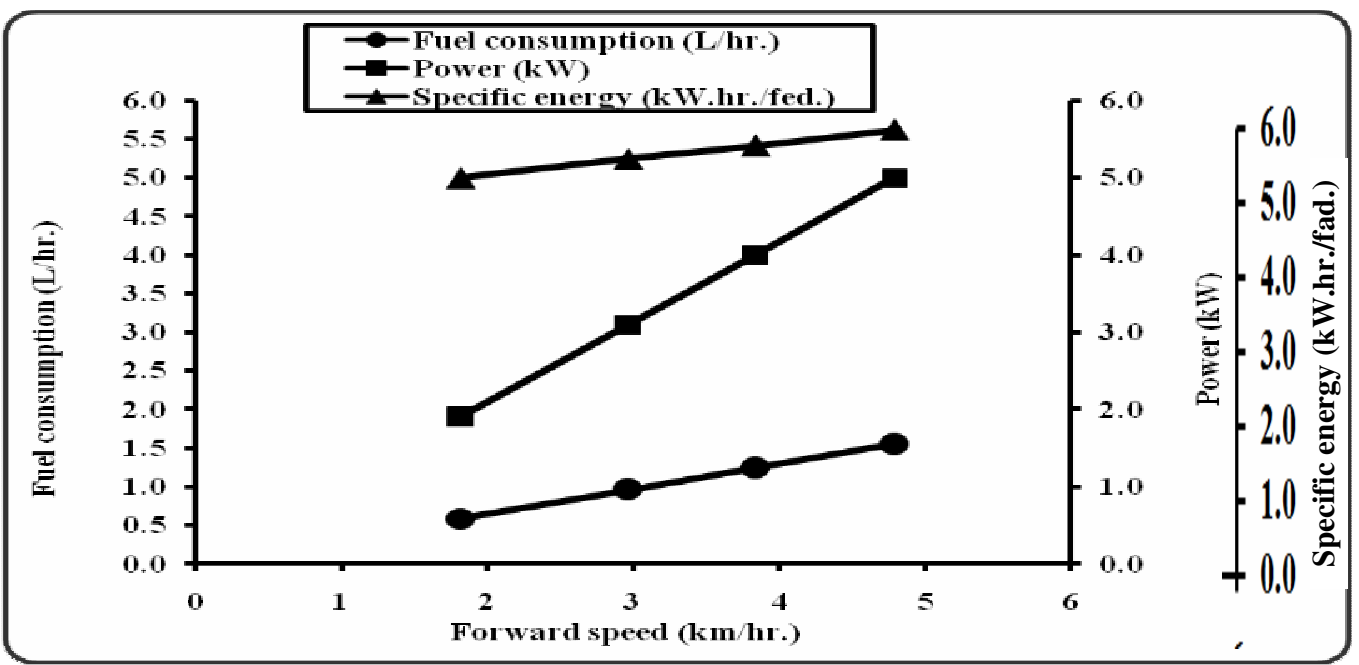

Fig. 12. Effect of forward speed on fuel consumption, power and specific energy

Table 2. Effect of forward speed on operation and production cost for marjoram mechanicalplanting

\begin{tabular}{ccc}
\hline Forward speed, km/hr. & Operation cost, LE/fad. & Production cost, LE/ton. \\
\hline 1.82 & 140.47 & 43.90 \\
2.97 & 91.49 & 34.52 \\
3.84 & 74.55 & 29.23 \\
4.79 & 62.42 & 26 \\
\hline
\end{tabular}

The maximum operation-cost of 140.47 LE/fad., was obtained by using forward speed of $1.82 \mathrm{~km} / \mathrm{hr}$. Meanwhile, the minimum operation-cost of 62.42LE/fad., was obtained by using forward speed of $4.79 \mathrm{~km} / \mathrm{hr}$.

The maximum production-cost of $43.90 \mathrm{LE} /$ ton was obtained by using forward speed of 1.82 $\mathrm{km} / \mathrm{hr}$. Meanwhile, the minimum productioncost of $26 \mathrm{LE} /$ ton was obtained by using forward speed of $4.79 \mathrm{~km} / \mathrm{hr}$.

\section{Conclusion}

The optimum forward speed for operating the developed coated-seeds planter was $2.97 \mathrm{~km} / \mathrm{hr}$., which gave the following results: seed emergence of $88.4 \%$, missing hills of $1.25 \%$, double seeds of $7.5 \%$, actual field-capacity of 0.59 fad./hr., field efficiency of $83.10 \%$ crop yield $2650 \mathrm{~kg} /$ fad., ground wheel slip of $3.97 \%$, Power of $3.10 \mathrm{~kW}$, specific energy 5.25 $\mathrm{kW} . \mathrm{hr}$./fad., operation cost of planter and tractor of $91.49 \mathrm{LE} / \mathrm{fad}$., and production cost of 34.52 LE/ton.

\section{REFERENCES}

Abd Al-Fattah, Y.A. (2016). Development of a seed-coating machine for some crops, Ph.D., Ag. and Bio-systems Eng. Dept., Fac. Agric., Moshtohor, Banha Univ.,17-124.

Abd-Al Fattah, Y.A., A.A. Bahnasawy, I. Yehia and T.A. Hassan (2015). Development of a seed-coating machine for pepper crop., The $20^{\text {th }}$ Ann. Conf. Misr Soc. Ag. Eng., 171-192.

Awady, M.N. (1978). Tractor and Farm Machinery, Textbook, Fac. Ag. Ain Shams Univ., 164167.

Chandra,K. and S.R. Ingle (2010). Bio-treated seeds. J. Eco- Friendly Agric., 5 (1): 1-20.

FAO Statistical Year Book (2017). World food and agriculture, Food and Agriculture Organization of the United Nations, Economic and Soc. Dev. Dept., Roma. 
Grewal, R.S. (2014). Development and evaluation of tractor operated planter for onion crop. M. Sc., Farm Machinery and Power Eng. Dept., Coll. Agric. Eng. and Technol. Punjab Agric. Univ., $32-33$.

Karayel, D. (2011). Direct Seeding of Soybean Using a Modified Conventional Seeder, Soybean-Applications and Technology, Published by InTech, available from: http:// www.intechopen.com/books/soybeanapplications-and-technology/direct-seedingof-soybean-using-amodified-conventionalseeder: 1-17.

Sahoo, P.K. and A.P. Srivastava (2008). Seed pattern characteristics of different metering systems for soaked okra seed. Misr J. Ag. Eng., 45 (1): 1-6.
Taylor, A.G., D.E. Klein and T.H. Whitlow (1998). SMP: solid matrix priming of seeds. Scientia Hort., 37:1-11.

Yehia, I. (1993). Design of a seed drill attached to a power tiller, M. Sc. Thesis, Fac. Agric., Ain Shams Univ., 57-140.

Yehia, I. (2008). Factors affecting the design of coating machine for crop seeds, Misr J. Ag. Eng., 25 (1): 147-159.

Yehia, I., M. Atallah, A. Eliwa and A.M. El Lithy (2010). Effect of coating temperature and time on germination of some aromatic and medical seeds, Misr J. Ag. Eng., 35(4): 1710-1720.

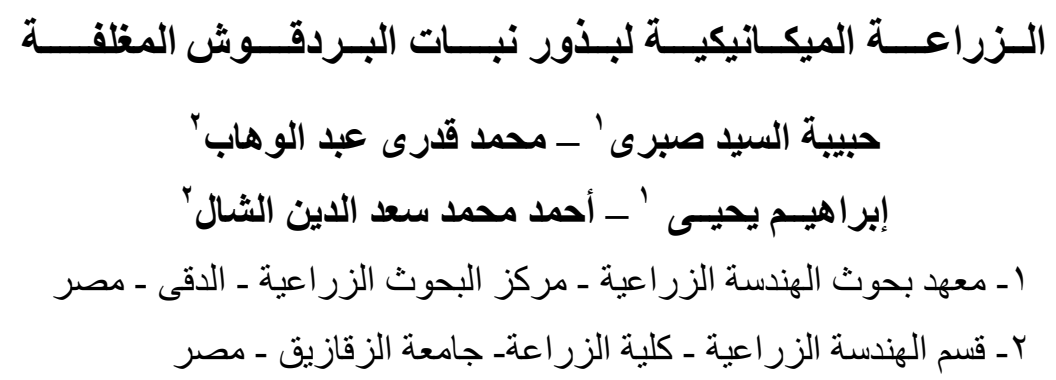

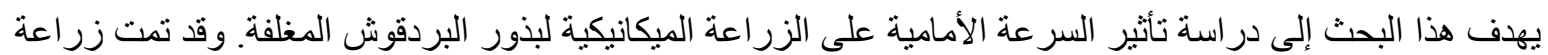

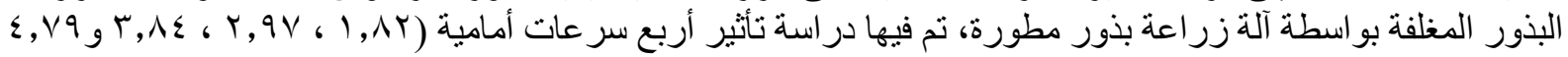

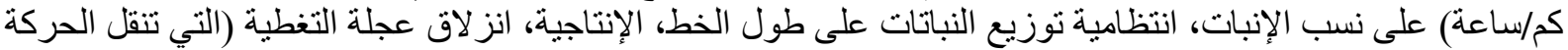

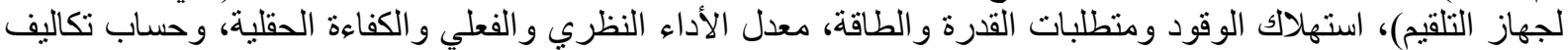

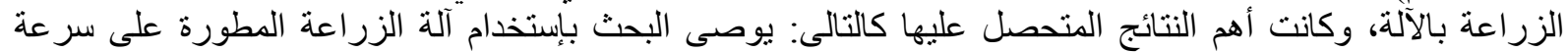

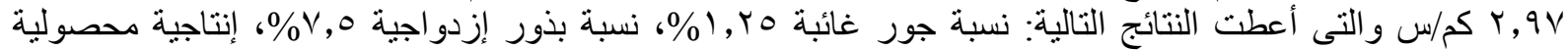

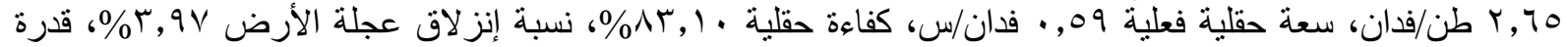

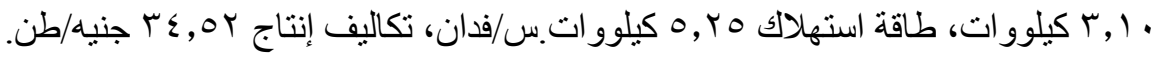

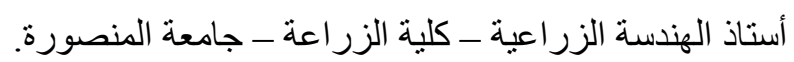
أستاذ ورئيس قسم الهندسة الزراعة الزية ــكلية الزر اعة الزعة - جامعة الزقازيق.

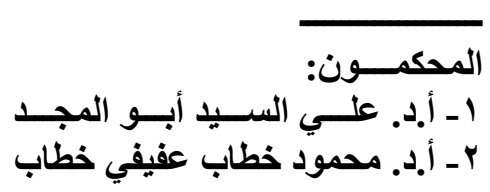

